Наталія Матвеєва, кандидат педагогічних наук, доцент ДВНЗ «Прикарпатський національний університет імені Василя Стефаника» (м. Івано-Франківськ, Україна)

\author{
Nataliia Matveieva, \\ Candidate of Pedagogic Sciences, Associate Professor \\ Vasyl Stefanyk Precarpathian national university \\ (Ivano Frankivsk, Ukraine) \\ nataliematveieva@gmail.com \\ ORCID 0000-0002-8495-7074
}

Удк 37.011.31

\title{
РОЗВИТОК ІНКЛЮЗИВНОЇ ОСВІТИ НА ПРИКАРПАТТІ
}

\begin{abstract}
Анотація. На сучасному етапі актуалізуємо проблеми інклюзивної освіти, що ґрунтуються на визнанні прав і свобод людини й, зокрема, з порушеннями розвитку. Філософський аспект інклюзії передбачає улаштування гуманного суспільства у цілому та толерантного інклюзивного середовища, зокрема, у навчальному закладі. У статті проаналізовано найбільш актуальні проблеми сьогодення, що торкаються означених питань. Здійснено порівняльний аналіз розвитку інклюзивного процесу на території України, виокремлено регіони, що перебувають у зоні так званого «ризику» щодо упровадження та подальшого розвитку інклюзивного навчання; забезпечення дітей шкільного віку з різними нозологіями якісними освітніми послугами; створення для них оптимальних умов соціалізації, навчання, виховання та розвитку. Так, з-поміж низки регіонів найбільш проблемними визнано гірські, що пояснюємо специфікою та віддаленістю розташування, неналежним забезпеченням педагогічними та медичними фахівцями, низьким рівнем обізнаності населення про інклюзію тощо.

Розкрито основні шляхи упровадження інклюзії на Прикарпатті, продемонстровано статистику, яка підтверджує позитивні зміни у їі розвитку. Акцентовано увагу на особливостях упровадження інклюзивного навчання у закладах ІваноФранківської області та міста; охарактеризовано його функціонально-змістові складові на основі аналізу результатів діяльності навчальних закладів дошкільної, початкової та середньої ланки; наведено позитивні досягнення та прогалини у контексті означеного. Виокремлено мету, завдання та напрями розвитку інклюзивної інфраструктури обласного центру. Вивчено, узагальнено та розкрито характеристики практичної роботи педагогів навчальних закладів на шляху створення інклюзивного середовища; опрацьовано та проаналізовано статистичні дані щодо включення осіб з особливими освітніми потребами у масові освітні заклади; встановлено основні прогалини та упущення даного.
\end{abstract}

Ключові слова: інклюзія, інклюзивна освіта, початкова школа, заклади середньої освіти, педагог, професійний рівень, робота в команді, психолого-педагогічний супровід.

\section{DEVELOPMENT OF INCLUSIVE EDUCATION IN THE CARPATHIANS}

Abstract. The article reveals the main ways of introduction and development of inclusion in Prykarpattia; features of educational inclusion on the basis of the analysis of activity of educational institutions of preschool, initial and average link are characterized; the purpose, tasks and directions of development of inclusive infrastructure of the regional center are singled out. The functional and semantic characteristics of the practical work of teachers of educational institutions on the way to creating an inclusive environment are studied, generalized and revealed; processed and analyzed statistical data on the inclusion of persons with special educational needs in mass educational institutions; identified the main gaps and omissions of this process at the present stage; further prospects for development are outlined.

Keywords: inclusion, inclusive education, primary school, secondary education institutions, teacher, professional level, team work, psychological and pedagogical support..

Inclusive education as an urgent need of time has covered all spheres of our life today. On the one hand, it is inclusion in education: the creation of new, more humanistic educational institutions in a traditional school, in which students with special educational needs study at the same level as their peers. On the other hand, it is social inclusion - one that involves the humanization of human relations, the establishment of relations between different social groups, the provision of social services to those who need them most. At the same time, we distinguish between political and economic inclusion, which reflect the level of development of our entire society, country, settlement (city, village); political and economic readiness to accept such persons into society, to create all necessary conditions for their living, study, treatment, professional activity, participation in public and political life, etc. The multifaceted nature of the problem is indicative of the all-encompassing scale of the inclusion of inclusion in our lives. However, practice shows that in different parts of our country, inclusion in education is developing differently. Of course, this depends on the needs of educational institutions, the number of school- 
age children with disabilities in the area, subsidies from the state and local authorities, community activity and sponsorship; the desire of society as a whole to support, help, create conditions for people with special needs for a full life.

The purpose of the article is to cover the problem of inclusive education development in Prykarpattya; highlighting the most pressing issues and prospects in this area.

Presentation of the main material. In Prykarpattya and, in particular, in the regional center, inclusive education is gradually paving its way. This is evidenced by the opening of new centers and institutions; new activities during the school year in secondary schools, the Institute of Postgraduate Education, higher education, aimed to increase the professional level of teachers in order to provide quality educational services to children with special educational needs. Issues of inclusive education are increasingly raised at meetings of heads of local authorities and self-government, principals of schools and preschools, social organizations, highlighting its various aspects: the availability of educational institutions to receive quality educational services; raising the professional level of teachers and educators; raising funds; adaptation of educational premises and environment; cooperation with families and more.

According to the report on the work of the Department of Education and Science of Ivano-Frankivsk City Council as of 2019, in our city there was active work to create the necessary conditions for the inclusion of preschool and school children with various types of developmental disabilities in mainstream schools (Report on the work of the Department of Education and Science, 2019). Thus, in 2019, a number of measures were taken to expand the network of preschool education institutions in the city. Today in Ivano-Frankivsk has trained about 9828 preschool children in such preschool institutions (Fig. 1):

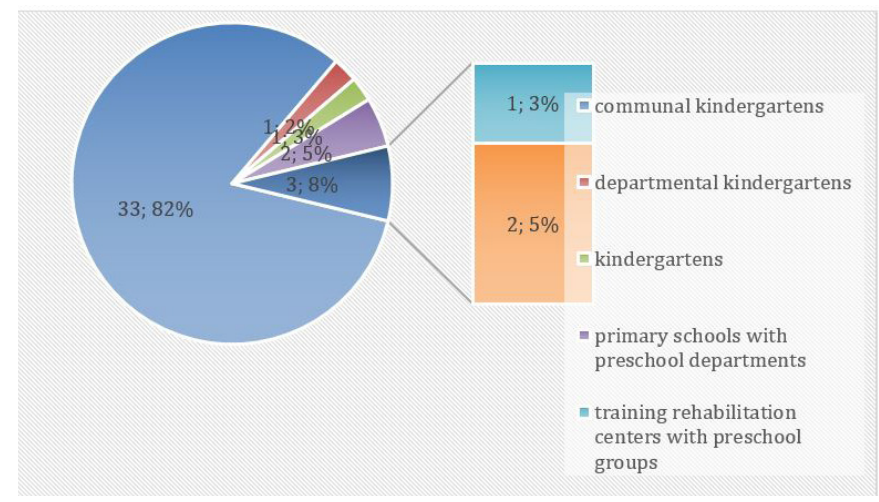

Fig. 1. The number of kindergartens in Ivano-Frankivsk (in 2020)

In order to introduce and develop inclusive education in preschool institutions (a total of 25), 53 inclusive groups were opened, in which preschool children with different types of nosologies could study.

The relevance and demand for inclusive education testify to the disappointing statistics on the large number of people with special educational needs, provided by medical institutions in our region. In particular the results conducted in 2019 by pediatricians month and preventive examination 29,348 school children found that all the patients are those who have some form of developmental disorders, such as:

- speech development disorders - 1353 children;

- visual acuity disorders - 1611 children;

- posture disorders - 102 children and with scoliosis - 60 children;

- with delayed physical development - 25 children;

- with disabilities - 673 children.

The recorded data of reports of medical institutions on the constant growth of the total number of children of different ages with one or another type of developmental disorder are disappointing. On the one hand, this is evidence of improper ecology in our region, and on the other - a low level of education of the people to preserve their own and Health ' I other (reproductive health ' I, nutrition, healthy sleep, active lifestyle and sports, etc.), failure to comply with health lifestyle, inadequate medical services and so on.

In furthering the year (01.06. 2018 - 01.08. 2019 g.) Utility company "inclusive resource center" of the city recorded about 470 calls from parents whose children requiring correction of physical and / or mental disabilities.

Accordingly, the number of persons with different types of violations is (Table 1).

In percentage terms, the number of children with different types of nosologies living and studying in our city is shown in:

1) complex violations - 7;

2) intellectual impairment - 29;

3) mental retardation - 101;

4) autism - 36;

5) severe speech disorders - 158;

6) musculoskeletal disorders - 41;

7) hearing impairment -46 ;

8) visual impairment -8 . 
The number of children with different types of nosologies (Ivano-Frankivsk)

\begin{tabular}{|c|c|c|c|c|c|c|c|c|}
\hline 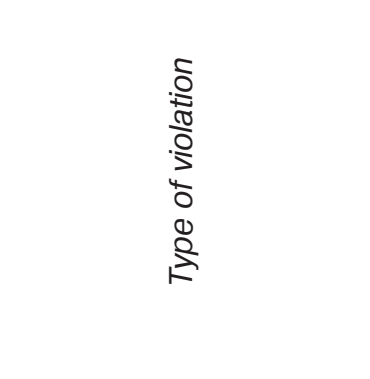 & 宽 & 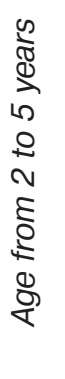 & 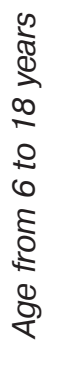 & 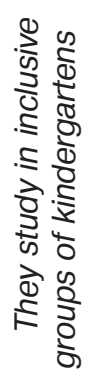 & 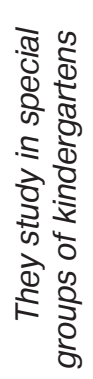 & 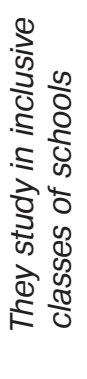 & 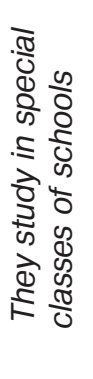 & 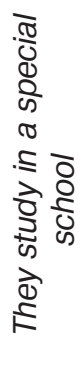 \\
\hline 1 & 2 & 3 & 4 & 5 & 6 & 7 & 8 & 9 \\
\hline Visual impairment & 8 & 1 & 7 & 1 & & 6 & 1 & \\
\hline Hearing impairment & 46 & 10 & 36 & 12 & & 15 & 3 & 16 \\
\hline Violation of ORA & 41 & 9 & 32 & 6 & 5 & 20 & 5 & 5 \\
\hline $\begin{array}{l}\text { With severe speech } \\
\text { disorders }\end{array}$ & 158 & 55 & 103 & 38 & 18 & 35 & 14 & 51 \\
\hline $\begin{array}{l}\text { With autism spectrum } \\
\text { disorders }\end{array}$ & 36 & 34 & 2 & 34 & & & & \\
\hline From ZPR & 101 & 18 & 83 & 22 & & 76 & & 2 \\
\hline $\begin{array}{l}\text { With impaired mental } \\
\text { development }\end{array}$ & 29 & 3 & 26 & 2 & 4 & 5 & 4 & 14 \\
\hline $\begin{array}{c}\text { With complex } \\
\text { developmental disorders }\end{array}$ & 7 & & 7 & & 1 & & 1 & 5 \\
\hline
\end{tabular}

Source: Report of the Inclusive Resource Center for 2019.

Shown in indicators are not evidence that only this number of children with various types of developmental disorders live in our city, as these are only data on appeals to the IRC. However, these figures suggest that the situation is complex and needs to be addressed immediately to provide this category of children with appropriate educational, medical, social and other services; introduction of inclusive education at all its levels (preschool, primary, secondary, higher, etc.). That is why the employees of the "inclusive -resource center " are performing a comprehensive assessment of psychological and educational development; participate in the development of an individual program for the development of a child with special educational needs; carry out maintenance of this category of persons in the inclusive first training; provide correctional and development services, etc. Along with that, "inclusive resource center" organizes a series of measures aimed at creating in our city a barrier-free inclusive environment that will allow us to implement plans and to satisfy the interests of children with special educational needs. The main ones are: organization of the location "Inclusive town" for children with special educational needs; holding joint family holidays, drawing exhibitions and more.

In terms of reforming traditional education and implementation of inclusive education in our city, special attention is paid to strengthening the health of children, ensuring physical activity, intensification of physical culture and health among students. In turn, the continuation of inclusive education in kindergartens is its development at the next stage - in secondary schools of our city. Educational network of general secondary education institutions in our city as of 2019/2020 years included (Table 2).

As our study shows, compared to last year, the actual network of secondary schools has increased by 49 classes (a total of 1479 students). The network of primary schools has increased by 20 grades (492 students), the growth rate is $8 \%$. Number of elementary school students is 12,947 people, which is the highest and the figure for the last 20 years.

According to the legal framework of inclusive education, its implementation in educational institutions of our city began to take place quite actively last year. Thus, children with developmental disabilities who have reached school age have the right to choose the educational institution that is located near their place of residence or at will. In addition, the city implements a number of measures for their socialization and integration into society by creating appropriate conditions and various centers, centers, as well as involving families, members of the public, social institutions to participate in the educational process. For example, in our city there is a Training and Rehabilitation Center, which enrolls 142 children, $50 \%$ of whom have the opportunity to receive education under the educational programs of general secondary education. In order to promote and implement inclusive education during 2019-2020 years. were discovered inclusive classes, which enrolled 120 children with special needs; 6 inclusive extended day groups were opened for 7 children with special educational needs. Along with that, put 104 workloads of teachers and in accordance with 6 of assistant teachers of the extended day groups. 
Development of the network of educational institutions of our city The number of children with different types of nosologies (Ivano-Frankivsk)

\begin{tabular}{|c|c|c|c|}
\hline Type of institution & $\begin{array}{c}\text { Number of } \\
\text { institutions in the city }\end{array}$ & $\begin{array}{c}\text { Number of } \\
\text { classes in schools }\end{array}$ & $\begin{array}{c}\text { Number of } \\
\text { students in classes }\end{array}$ \\
\hline 1 & 2 & 3 & 4 \\
\hline Schools & 42 & 1091 & 29524 \\
\hline $\begin{array}{l}\text { in including: } \\
- \text { private schools; } \\
- \text { training and rehabilitation } \\
\text { center for children with } \\
\text { special needs }\end{array}$ & 4 & 42 & 142 \\
\hline
\end{tabular}

The adaptation and modification of educational institutions to the needs of students with developmental disabilities is also indicative. For example, the two schools of our city (No 1, 17) created the resource room for emotional first Unloading spare schoolchildren, created resource rooms for emotional relief of students, relieving stress and reducing anxiety, increasing the level of cognitive activity, creating opportunities for individual lessons with specialists. Local authorities and the Department of Education and Science are striving to computerize educational institutions; equip schools appropriately equipment and devices that are essential for the organization of inclusive education.

Instead, in early 2019 the first steps were taken to individualize the education of children (educational institutions of IvanoFrankivsk at the request of parents in accordance with the Regulations on the individual form of 10 students transferred to the family form of education); various available forms of education are considered.

Along with that, in our city are organized and provided conditions for teacher training courses for the typical educational program developed under the concept of the new Ukrainian school. Teachers have passed the obligatory stage of advanced training on the website of the online education studio EdEra (three sessions - 72 hours of training) under the Standard educational program of advanced training of teachers. In order to prepare teachers for work in the New Ukrainian School and inclusive education, various forms of in-service teacher training are systematically conducted, such as webinars, seminars ("Organization of effective use of interactive teaching aids in the New Ukrainian School"), workshops, conferences, trainings training ("Professional competence of a teacher of the New Ukrainian school", "Innovative technologies in primary school: prospects and deltas"); - a workshop and ("STEM-education in elementary school") and so on.

Therefore, the above suggests that inclusion is gradually developing and gaining momentum in the Carpathians and not only in the field of education, but also in the other areas of life.

\section{REFERENCES}

Report on the work of the Department of Education and Science of Ivano-Frankivsk City Council for 2019 year. URL: http://www.mvk.if.ua/ uploads/files/52191.pdf

Report of the Inclusive Resource Center for 2019. URL: https://ircenter.gov.ua/irc/view-report/id/85919/type/1irc?export=html

Kolupaeva, A.A. (2009) Inclusive education: realities and prospects: a monograph. Kyiv: Summit-Book.

The concept of the New Ukrainian School was approved by the Decision of the Board of the Ministry of Education 27.10.2016. URL: http://zakinppo.org.ua/images/2017/docs/10/konczepcziya.pdf 